ISA

Arboriculture \& Urban Forestry 2016. 42(3): 192-200

\title{
Effect of Mulching with Compost on Growth and Physiology of Ulmus 'FL634' Planted in an Urban Park
}

\author{
Alessio Fini, Ciro Degl'Innocenti, and Francesco Ferrini
}

\begin{abstract}
The effects of mixed compost as mulching material on growth and physiology of newly planted elm trees were evaluated over a three-year period after planting in an urban park. Trees mulched with compost generally had greater height $(+10 \%$ and $+19 \%$ for $5 \mathrm{~cm}$ layer and $10 \mathrm{~cm}$ layer treatments, respectively, if compared to control), trunk diameter $(+13 \%$ and $+29 \%)$, and current-year shoot growth $(+46 \%$ and $+56 \%)$. Limited effects were found with regard to carbon assimilation when considered on a per unit-leaf-area basis $(-0.1 \%$ and $+0.3 \%)$, but whole tree carbon assimilation increased in mulched trees $(+7 \%$ and $+59 \%$ for $5 \mathrm{~cm}$ and $10 \mathrm{~cm}$ treatments, respectively, if compared to control) because of the larger total tree leaf area of mulched plants. Mulching also increased chlorophyll content (+ $4 \%$ and $+7 \%$ for $5 \mathrm{~cm}$ and $10 \mathrm{~cm}$ treatments, respectively). The results obtained in this study show how mulching with compost increased growth, carbon storage, and improved water use efficiency of trees planted in an urban environment characterized by hot dry summers.

Key Words. Carbon Assimilation; Chlorophyll; Elm; Florence; Italy; Mediterranean Climate; Mulch; Photosynthesis; Ulmus; Water Use Efficiency.
\end{abstract}

Mulching is a widely used technique in the United States and in Northern European countries thanks to its beneficial effects, such as improved early growth of trees, increased root development, reduction in soil summer temperature, greater water availability, maintenance of good soil structure and porosity, and limitation of soil erosion caused by stormwater (Chalker-Scott 2007). Organic mulches (e.g., shredded wood, chipped wood, pine bark, and composted materials) are of particular interest because of their positive effects on soil physical, chemical, and biological properties (Fraedrich and Ham 1982; Litzow and Pellett 1983; Watson 1988; Appleton et al. 1990; Himelick and Watson 1990; Smith and Rakow 1992; Lloyd et al. 2000; Tiquia et al. 2002; Dahiya et al. 2007; Ferrini et al. 2008a), resulting in enhanced plant growth and leaf gas exchange in most mulching experiments (Watson 1988; Green and Watson 1989; Appleton et al. 1990; Himelick and Watson 1990; Ferrini et al. 2008b; Fini and Ferrini 2011; Scharenbroch and Watson 2014). Mulching with organic materials was shown to mitigate temperature in the underlying soil (Iles and Dosmann 1999;
Ferrini et al. 2008a; Fini and Ferrini 2011), which may be critical for root growth in Mediterranean climates, where summer soil temperature often exceeds $32^{\circ} \mathrm{C}-35^{\circ} \mathrm{C}$, the threshold limit for root growth (Graves 1998). Organic mulching was also shown to increase soil moisture (Kraus 1998; Lakatos et al. 2000; Ferrini et al. 2008a; Scharenbroch and Watson 2014) more often than decreasing it (Gilman and Grabosky 2004), to increase soil total organic carbon and mineral nutrient availability while reducing soil bulk density (Ferrini et al. 2008a; Scharenbroch and Watson 2014), and to trigger soil biological activity through the enhancement of soil microbiota and invertebrates (Tiquia et al. 2002; Jordan and Jones 2007). However, results from mulching can be variable depending on climatic and soil conditions, on tree species, on the physico-chemical characteristics of the material used as mulch, and on how mulches are distributed on the soil (Whitcomb 1979; Dureya et al. 1999; Iles and Dosmann 1999; Townsend et al. 2003; Arnold et al. 2005). For example, adding too much fine-textured material (e.g., more than $25 \mathrm{~cm}$ ) can adversely affect soil oxygen content and water 
infiltration (Gilman and Grabosky 2004; Arnold et al. 2005; Hanslin et al. 2005), while no detrimental effects were found after the application of $0.45 \mathrm{~m}$ of a coarse mulch (wood chip) over the soil in which the roots of trees were growing (Watson and Kupkowski 1991). Among the organic material suitable as mulches, compost is an excellent candidate. In fact, composting also decreases environmental problems related to the management of wastes by their reducing volume and by killing potentially dangerous organisms (Sæbø and Ferrini 2006). While green wastes from gardens and parks previously made up the largest proportion of materials for composting, recently other materials have become even more important: separated household wastes, organic wastes from agriculture and the food-processing industry, among others. Thus, the use of composted waste as mulch in urban green areas may fit strong sustainability criteria by creating resources from waste. Urban green areas can benefit from the availability of compost products because of the large potential for improvement of growing conditions of trees and shrubs cultivated in urban soils low in organic matter (Sæbø and Ferrini 2006). Potential benefits and disadvantages of mulching with compost largely depend on compost quality, stability, and maturity (soil pollution, salinity and anoxia are likely to occur if these requirements are not satisfied, for details, see Sæbø and Ferrini 2006), but also on the size of particles and carbon to nitrogen $(\mathrm{C}: \mathrm{N})$ compost ratio, which greatly affect mineralization rate (Cogger 2005). In previous experiments conducted in nursery plots, mulching with coarse, high C:N compost provided an effective control of weeds and positive effects on soil chemico-physical traits and plant growth (Ferrini et al. 2008a; Ferrini et al. 2008b). In a similar experiment, mulching with fine, low $\mathrm{C}: \mathrm{N}$, had positive effects of soil temperature, soil water availability, soil biological activity, and plant growth, but was less efficient in controlling weeds (weeds started to grow on the compost layer in the next growing season after compost was laid, and re-distribution of compost was required) (Fini and Ferrini 2011). Clearly, the fast mineralization of fine, low C:N compost provides nutrients that can trigger a fast growth rate of the weeds germinated on the mulch layer. Typically, mulching with fine compost controls weeds for no longer than one year, while using coarse compost allows a satisfactory weed control up to three years (Ferrini et al. 2008b).
While extensive studies on mulching with compost have been carried out in temperate areas, limited information is available for zones with warmer and/or drier climates. Similarly, the study authors are not aware of field experiences in urban sites with very dry summers, and so the purpose of the present study was to investigate the use of mixed compost as mulching material and its possible influence on growth and physiology of elm (Ulmus) trees planted in a Mediterranean urban park, with summers characterized by limited rainfall and high temperatures.

\section{MATERIALS AND METHODS}

In late winter 2009 , uniform $1.5 \mathrm{~m}$ tall and $1.0 \mathrm{~cm}$ diameter cutting-propagated elm trees of clone FL634 (a hybrid elm clone selected by IPSP-CNR for Dutch elm disease resistance) (Santini et al. 2010) were planted in an urban park located in Florence, Italy $\left(43^{\circ} 46 \mathrm{~N}, 11^{\circ} 15 \mathrm{E}\right)$. Mean temperatures, rainfall, and ETP data for Florence over the period 1981 to 2010, and of the years when the experiment was conducted (2009-2011), were provided by LaMMA Consortium (LaMMA 2014).

Mean temperatures and rainfall in Florence over the period $1981-2010$ were $14.9^{\circ} \mathrm{C}$ and $872.6 \mathrm{~mm}$ year $^{-1}$, respectively. However, during the years of the present experiment, an increase in mean temperatures were recorded $\left(16.1^{\circ} \mathrm{C}\right.$ versus $\left.14.9^{\circ} \mathrm{C}\right)$ as well as a decrease in rainfall in the first and third year (784.4 $\mathrm{mm}$ and $588.8 \mathrm{~mm}$, respectively) with an extended dry period with almost no rainfall from mid-June to the end of August (5 mm in 2009 and 51.2 in 2011), while 2010 was quite rainy. Similarly, the summer of 2010 was characterized by a $25 \%$ lower potential evapotranspitation (ETP) if compared to 2009 and 2011 (data not shown). Lower rainfall and higher ETP resulted in summer 2009 and 2011 being much drier than summer 2010, as also shown by the net balance between rainfall and ETP (Figure 1).

The native substrate was the result of an excavation done 15 years before for the construction of buildings nearby, and it was a silty clay loam soil, according to Juma(1999), with averylownutrient content(Table1).

Two-year-old plants, having nearly identical size characteristics, were obtained from the Institute for Sustainable Plant Protection of the National Research Council of Italy (IPSP-CNR). Trees were planted in a single row, spaced $5 \mathrm{~m}$ from each other. Within the row, mulching treatments were 


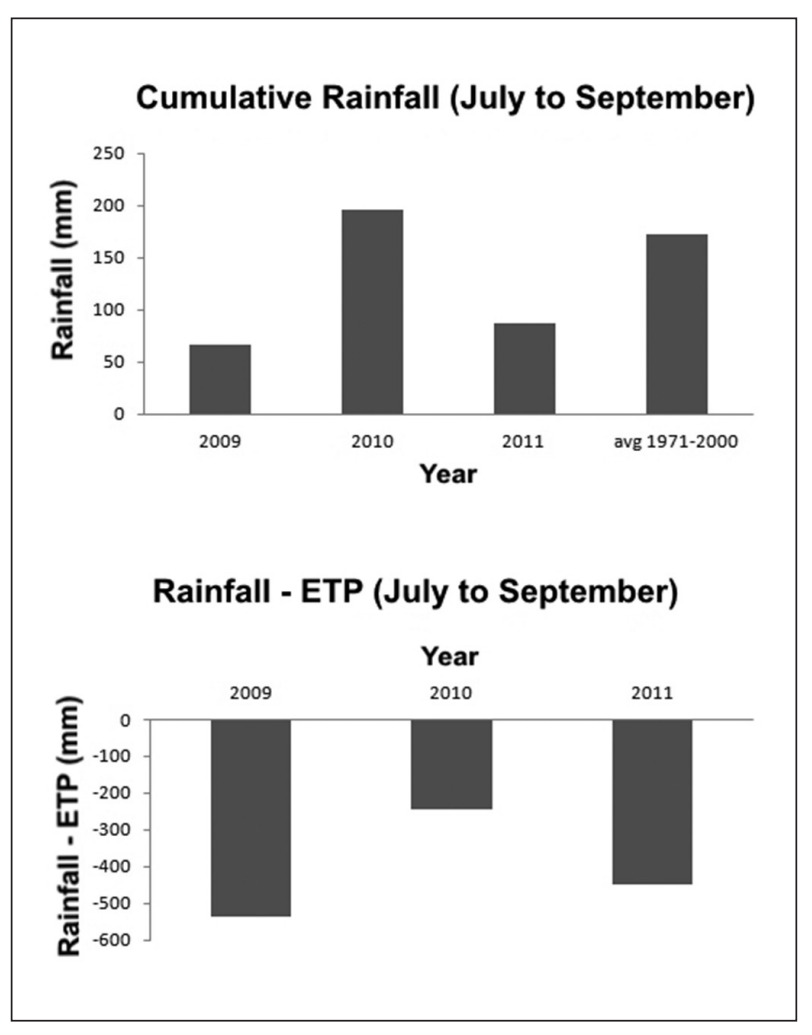

Figure 1. Cumulative rainfall at the experimental site during the summer period, during the years of measurement compared to the average between 1971 and 2000, and difference between rainfall and evapotranspiration.

imposed according to a randomized block design, with 13 blocks and one plant per treatment in each block (total of 39 plants). Mulching was laid around the trunk using four boards nailed to a 1 $\mathrm{m}^{2}$ square according to the following treatments:

- mulching with $5 \mathrm{~cm}$ layer of mixed compost obtained from the local composting plant and made of a mix of green material and kitchen wastes (treatment $5 \mathrm{~cm}$ )

- mulching with $10 \mathrm{~cm}$ of the same material (treatment $10 \mathrm{~cm}$ )

- $\quad$ no mulching (control)

Mulching was not added in the following years, and the soil around control plants was kept free of grasses by regular hand weeding.

Chemical analyses of the compost were performed according to standard methods (Faithfull 2002) and showed values fitting to national legislation limits for all parameters (Table 2). The compost used was subalkaline, with a C:N around 30, a medium to high content of humus and organic carbon.
Planting holes were as deep as the root ball and two times its width to ensure a sufficient volume of loose soil within the planting hole. The sides of the planting pit were scarified with a shovel to $1 \mathrm{~m}^{2}$ surface. At planting, care was taken that the root flare was not positioned below soil level.

Plants were irrigated the first year after planting by hand watering once a week to help establishment. Two years after planting, all temporary branches attached to the trunk at a height lower than $2 \mathrm{~m}$ were pruned, according to standard practices for public gardens. Pruning did not remove more than $15 \%$ of leaf area. Only removal cuts were used [i.e., selected branches were removed at their attachment to the trunk, as described in Fini et al. (2015)].

Starting from the first growing season, the following parameters were measured:

1) plant height (only in the first two growing seasons), measured from the root flare to the terminal bud of the apical leader

2) trunk diameter (determined on each plant at the end of each growing season), measured at breast height $(1.3 \mathrm{~m})$

3) shoot length (determined on 20 shoots per plant on all plants at the end of the growing season) measured from the apical bud of the shoot to the point where current year growth began

4) average leaf area measured on 20 leaves per plant on all plants that were harvested in September and immediately scanned on an A-3 scanner; image processing was carried out with Image Tool 3.0 (University of Texas, Health Science Center, San Antonio, Texas, U.S.). Total leaf area per plant $\left(\mathrm{m}^{2}\right)$ was calculated in the first growing season after counting all the leaves of five plants per each treatment and multiplying by average leaf area

5) leaf dry mass determined on the same leaves used for leaf area, after drying them in an oven at $70^{\circ} \mathrm{C}$ until constant weight was reached (approx. 72 hours); leaf mass per area (LMA, $\mathrm{g} \mathrm{DWm}^{-2}$ ) was calculated as the ratio between leaf dry mass and leaf area

6) fresh weight of the pruning material after pruning all branches and twigs attached in the lowest $2 \mathrm{~m}$ of the stem on all plants

7) leaf gas exchange [instantaneous net photosynthesis $(\mathrm{Pn})$, transpiration rate $(\mathrm{E})$, water use efficiency (WUE, calculated by dividing Pn by E)], measured two times each year dur- 
Table 1. Soil analysis. Data are the average of five different samples taken in the planting area.

\begin{tabular}{lcccccccccccc}
\hline Gravel \% & Sand & Silt & Clay & $\begin{array}{l}\text { Active } \\
\text { lime }\end{array}$ & $\mathrm{pH}$ & $\begin{array}{l}\text { Organic } \\
\text { matter }(\%)\end{array}$ & $\mathrm{N}(\%)$ & $\mathrm{K}_{2} \mathrm{O}(\mathrm{ppm})$ & $\mathrm{P}_{2} \mathrm{O}_{5} \mathrm{ppm}$ & $\begin{array}{l}\mathrm{CEC} \\
(\mathrm{meq} / 100 \mathrm{~g})\end{array}$ \\
\hline 2.0 & 16.6 & 53.3 & 30.1 & 1.0 & 8.0 & 1.5 & 0.1 & 132.94 & 12 & 25 \\
\hline
\end{tabular}

Table 2. Compost analysis. Data are the average of 10 different samples taken in the compost shipped to the planting area. Volatile solids are the fraction of compost that is lost after 24 hours in oven at $105^{\circ} \mathrm{C}$. They include humic and fulvic acids, nonhumic organic matter, and nutrients in volatile forms. Data are expressed over dry matter (DM) of compost.

\begin{tabular}{|c|c|c|c|c|c|c|c|c|c|c|}
\hline $\begin{array}{l}\text { Humidity } \\
\text { (\%) }\end{array}$ & $\begin{array}{l}\text { Glass and plastic } \\
\text { (g/100 g DM) }\end{array}$ & $\begin{array}{l}\text { Total carbon } \\
\text { (g/100 g DM) }\end{array}$ & $\begin{array}{l}\text { Volatile solids } \\
\text { (g/100 g DM) }\end{array}$ & $\begin{array}{l}\text { Humic and fulvic } \\
\text { acids (g/100 g DM) }\end{array}$ & $\begin{array}{l}\text { Ashes } \\
\text { (g/100 g DM) }\end{array}$ & $\begin{array}{l}\mathrm{N} \\
(\mathrm{g} / 100 \mathrm{~g} \mathrm{DM})\end{array}$ & $\begin{array}{l}\mathrm{P}_{2} \mathrm{O}_{5} \\
(\mathrm{~g} / 100 \mathrm{~g} \mathrm{DM})\end{array}$ & $\begin{array}{l}\mathrm{K}_{2} \mathrm{O} \\
(\mathrm{g} / 100 \mathrm{~g} \mathrm{DM})\end{array}$ & $\mathrm{pH}$ & C:N \\
\hline 35.74 & 1.03 & 28.29 & 64.28 & 11.59 & 34.69 & 0.92 & 0.11 & 1.70 & 7.38 & 30.66 \\
\hline
\end{tabular}

ing the summer period; leaf gas exchange was measured using the CIRAS- 2 portable infrared gas analyzer (PP-Systems, Hertfordshire, UK). The readings were taken between 9:00 am and $12: 30 \mathrm{pm}$, which was presumed to be the diurnal period when photosynthetic rates would be maximal, on sunny days under fixed $\mathrm{CO}_{2}$ concentration $\left(\mathrm{C}_{\mathrm{a}}=380 \mathrm{ppm}\right)$ and saturating irradiance $\left(1300 \mu \mathrm{mol} \mathrm{m} \mathrm{m}^{-2} \mathrm{~s}^{-1}\right.$ provided by a built-in red-light-emitting diode radiation source); measurements were conducted on 90 fully expanded leaves (three per treatment and block) selected from the outer part of the crown and at different heights (Fini et al. 2009); whole-canopy photosynthesis was calculated from Pn and leaf area; the plant modelling system WIMOVAC (v. 0.0.9, University of Illinois) was used to eliminate inaccuracies due to self-shading of the canopy

8) leaf greenness index was determined on five leaves with a portable chlorophyll meter (SPAD-502 Minolta Corp., Ramsey, New Jersey, U.S.); previous calibration curves were established by measuring absorbance at 664 , 647, and $625 \mathrm{~nm}$ with a spectrophotometer (U-2000, Hitachi High Technologies America, Inc., Schaumburg, Illinois, U.S.), after extraction with dimethylformamide (DMF); triplicate readings were taken around a midpoint near the midrib of each leaf and then averaged

9) presence of weeds on the mulch was visually checked 3 months and 12 months after mulch was laid.

\section{Statistical Analyses}

All data were subjected to one-way analysis of variance (ANOVA) using SPSS 20.0 statistical package for Windows ${ }^{\circledR}$ (SPSS Inc., Chicago, Illinois, U.S.), and means were separated using
HSD test $(P \leq 0.05)$. Data on leaf gas exchange have been processed per single sampling date, merged together, and processed again to obtain the average value on an annual basis.

\section{RESULTS AND DISCUSSION}

\section{Effects of Mulching on Growth and Leaf Area}

Mulching with compost positively affected shoot growth of elm trees over the entire period of measurements (Table 3). Mulched plants had greater shoot growth than the other treatments, regardless of layer thickness. It was only in the third year that trees with the $5 \mathrm{~cm}$ layer did not show statistical difference with respect to the control.

Plant height was greater in the $10 \mathrm{~cm}$ layer treatment, especially when compared to the control. Trunk diameter at planting was similar $(P>0.05)$ among treatments (data not shown). However, since the end of the first growing season, trunk diameter was greater in $10 \mathrm{~cm}$ treatment compared to the $5 \mathrm{~cm}$ group, which, in turn, showed greater diameter than control in the first and third year after planting (Table 3).

Pruning weight (measured two years after planting) was more than twice as much in the mulched trees compared to control. Greater plant growth in response to mulching has been observed by many authors (Chalker-Scott 2007; Ferrini et al. 2008b; Fini and Ferrini 2011), despite the temporary $\mathrm{N}$-immobilization that can follow the application of mulches with high C:N or high (lignin + polyphenol): $\mathrm{N}$ ratio (Palm 1995; Ferrini et al. 2008a; TerAvest et al. 2011; Rhoades et al. 2012). Others authors, however, found no $\mathrm{N}$-immobilization after the 
Table 3. Shoot growth, trunk diameter (at $130 \mathrm{~cm}$ ), plant height, average area of one leaf, leaf number per plant, total leaf area per plant, leaf mass per area (LMA), weight of the pruning material after pruning all branches attached in the lowest $2 \mathrm{~m}$ of the stem, net photosynthesis (Pn) of the whole canopy, and leaf greenness index of elm trees growing with no mulch or with either $5 \mathrm{~cm}$ or $10 \mathrm{~cm}$ mulch layer composed of a mix of green material and kitchen wastes. Different letters within the same row indicate significant differences among treatments at $P<0.01$ using Tukey's HSD test.

\begin{tabular}{|c|c|c|c|c|}
\hline \multirow[t]{2}{*}{ Parameter } & \multirow[t]{2}{*}{ Year } & \multicolumn{3}{|l|}{ Treatment } \\
\hline & & Control & $5 \mathrm{~cm}$ layer & $10 \mathrm{~cm}$ layer \\
\hline \multirow[t]{3}{*}{ Shoot elongation $(\mathrm{cm})$} & 1st year & $52.5 \mathrm{~b}$ & $80.8 \mathrm{a}$ & 82.9 a \\
\hline & 2nd year & $44.11 \mathrm{~b}$ & $67.77 \mathrm{a}$ & $71.02 \mathrm{a}$ \\
\hline & 3rd year & $31.37 \mathrm{~b}$ & $38.83 \mathrm{ab}$ & $45.37 \mathrm{a}$ \\
\hline \multirow[t]{3}{*}{ Trunk diameter at $130 \mathrm{~cm}$} & 1st year & $1.4 \mathrm{c}$ & $1.7 \mathrm{~b}$ & $2.1 \mathrm{a}$ \\
\hline & 2nd year & $3.42 \mathrm{~b}$ & $3.91 \mathrm{~b}$ & $4.42 \mathrm{a}$ \\
\hline & $3 r d$ year & $4.95 \mathrm{c}$ & $5.59 \mathrm{~b}$ & $6.37 \mathrm{a}$ \\
\hline \multirow[t]{2}{*}{ Plant height (m) } & 1st year & $3.40 \mathrm{c}$ & $4.34 \mathrm{ab}$ & $4.65 \mathrm{a}$ \\
\hline & 2nd year & $5.24 \mathrm{c}$ & $5.77 \mathrm{~b}$ & $6.23 \mathrm{a}$ \\
\hline \multirow[t]{3}{*}{ Leaf area $(\mathrm{cm})$} & 1st year & $28.61 \mathrm{a}$ & $28.72 \mathrm{a}$ & $31.96 \mathrm{a}$ \\
\hline & 2nd year & $31.07 \mathrm{a}$ & $31.34 \mathrm{a}$ & $33.23 \mathrm{a}$ \\
\hline & 3rd year & $28.46 \mathrm{a}$ & $30.39 \mathrm{a}$ & $31.53 \mathrm{a}$ \\
\hline Leaf number/plant & 1st year & $344.82 \mathrm{~b}$ & $376.96 \mathrm{~b}$ & $586.58 \mathrm{a}$ \\
\hline Total leaf area/plant $\left(\mathrm{m}^{2}\right)$ & 1st year & $0.98 \mathrm{~b}$ & $1.08 \mathrm{~b}$ & $1.87 \mathrm{a}$ \\
\hline \multirow[t]{3}{*}{ LMA $\left(\mathrm{g} / \mathrm{m}^{2}\right)$} & 1st year & $84.9 \mathrm{a}$ & $94.7 \mathrm{a}$ & $99.9 \mathrm{a}$ \\
\hline & 2nd year & $79 a$ & $75 \mathrm{a}$ & $77 \mathrm{a}$ \\
\hline & 3rd year & $113.7 \mathrm{a}$ & $113.9 \mathrm{a}$ & $115.6 \mathrm{a}$ \\
\hline Pruning weight (g) & 2nd year & $228.77 \mathrm{~b}$ & $467.62 \mathrm{a}$ & $484.68 \mathrm{a}$ \\
\hline Pn on whole plant basis (g hour ${ }^{-1}$ ) & 1st year & $0.42 \mathrm{~b}$ & $0.45 \mathrm{~b}$ & $0.67 \mathrm{a}$ \\
\hline \multirow[t]{3}{*}{ Leaf greenness index (SPAD units) } & 1st year & $39.8 \mathrm{~b}$ & $44.4 \mathrm{a}$ & $45.7 \mathrm{a}$ \\
\hline & 2nd year & $47.2 \mathrm{~b}$ & $50.0 \mathrm{a}$ & $50.1 \mathrm{a}$ \\
\hline & 3 rd year & $49.7 \mathrm{a}$ & $48.4 \mathrm{a}$ & $50.0 \mathrm{a}$ \\
\hline
\end{tabular}

application of high C:N mulches (Greenly and Rakov 1995; Pickering and Shepherd 2000), and the subject is still under debate. The mulch applied in this experiment had a $\mathrm{C}: \mathrm{N}$ ratio a little higher than that proposed as threshold between mineralization and immobilization (about 27, see Myers et al. 1994; Seneviratne 2000), so even some nitrogen immobilization might have occurred, growth was not affected even in the first year after application, in agreement with previous works (Tilander and Bonzi 1997; Erhart and Hartl 2003; Sonsteby et al. 2004; Granatstein and Mullinix 2008).

No differences were found in single leaf area, but in the first year, when all the leaves were counted and total leaf area per plant was calculated, both total leaf number and total leaf area/plant were higher in the $10 \mathrm{~cm}$ treatment. LMA was not affected by the mulching.

\section{Effect of Mulching on Leaf Gas} Exchange and Leaf Greenness Index

Leaf greenness index was generally higher in mulched plants (although in 2011 they were not statistically significant) (Table 3 ). Higher leaf greenness index following low $\mathrm{C}: \mathrm{N}$ mulch application were also found by Granatstein and Mullinix (2008), who noted soil N-enrichment due to mulch mineralization. Leaf greenness index has shown to be an accurate prediction of leaf $\mathrm{N}$ content (Follett et al. 1992; Wood et al. 1992; Percival et al. 2008). The effect of mulching on soil and leaf nitrogen was not measured; however, according to Percival et al. (2008), the higher SPAD-reading of mulched plants may reflect a better nutritional status generated by mulch application and its decomposition.

Leaf gas exchange per unit leaf area was not affected by mulching (Figure 2). In the first year, when trees were small and the entire leaf area was measured, assimilation on a whole-plant 
basis was higher in the $10 \mathrm{~cm}$ treatment (Table 3 ). It can also be hypothesized that as mulched trees are bigger and with longer shoots, they would be expected to have a greater leaf gas exchange on a whole-plant basis even in the following years. The higher net photosynthesis observed in summer 2010 in all treatments is consistent with the more humid environmental conditions observed in this summer when compared with summer 2009 and 2011.

Water use efficiency was greater in trees mulched with $10 \mathrm{~cm}$ layer in the second and third growing seasons compared to the other treatments (Figure 2). WUE in this research, considered as the ratio of carbon gain during $\mathrm{CO}_{2}$ assimilation $\left(\mathrm{A}, \mu \mathrm{mol} \mathrm{m} \mathrm{m}^{-2} \mathrm{~s}^{-1}\right)$ to water loss during transpiration $\left(\mathrm{E}, \mathrm{mmol} \mathrm{m}^{-2} \mathrm{~s}^{-1}\right)$, is of major importance to the survival, productivity, and fitness of individual plants. In fact, it has been generally demonstrated that increased WUE can be a water conservation measure, indicating that more carbon can be accumulated for growth with the use of less water (Nilsen and Orcutt 1996; Jones 2004).

\section{Efficiency in Weed Control}

Mulching with fine compost provided a satisfactory weed control only in the first months after application. Twelve months after application, the thickness of the mulch layer was either greatly reduced (10 $\mathrm{cm}$ treatment) or mulch had disap- peared (5 $\mathrm{cm}$ application), and weeds started to germinate and grow on the mulched plots. However, as shown by growth parameters, competition for nutrients between weeds and trees had no negative impact on trees, probably because the amount of nutrients released by organic mulch mineralization exceeded nutrient uptake by weeds. If a good weed control is desired, however, use of coarse compost or overlying a coarse compost layer to the fine compost may provide better results (Ferrini et al. 2008a; Ferrini et al. 2008b).

\section{CONCLUSIONS}

The results obtained in this study clearly show how mulching with mature and stable compost increased growth and leaf gas exchange of trees planted in an urban environment characterized by hot and dry summers. Mulched trees showed greater diameter and shoot growth, and higher whole-plant carbon assimilation than those grown on bare soil, and the positive effects of mulching increased with the thickness of the mulch layer (in this study, layers up to $10 \mathrm{~cm}$ thick were compared). The results from this study may provide a useful tool for landscape architects, urban planners and municipalities to increase sustainability of the management of green areas, and at the same time, to facilitate the reuse of municipal organic wastes after composting. To the knowledge and literature available, this study is one of the first tests of effec-

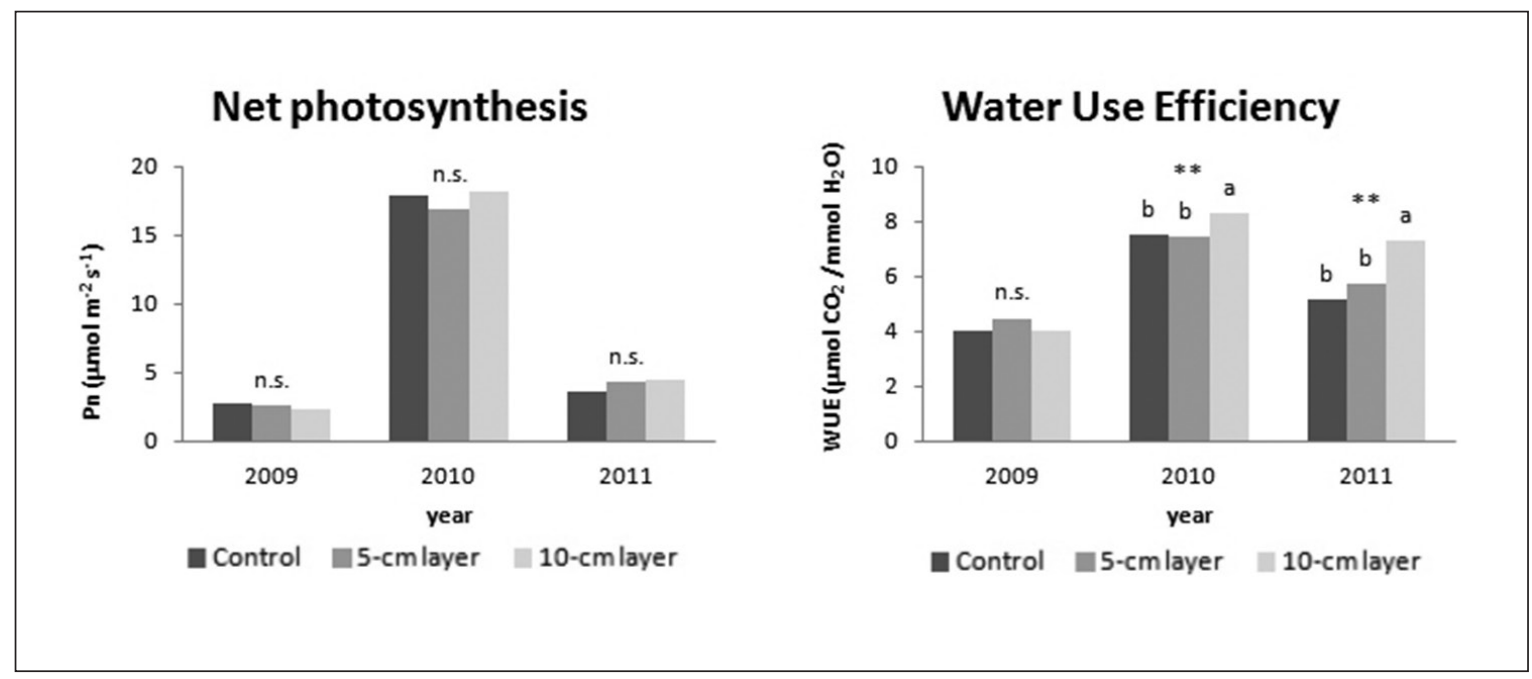

Figure 2. Net photosynthesis per unit leaf area $\left(\mu \mathrm{mol} \mathrm{m} \mathrm{m}^{-2} \mathrm{~s}^{-1}\right.$ ) and water use efficiency ( $\mu \mathrm{mol} \mathrm{CO}_{2}$ fixed/mmol $\mathrm{H}_{2} \mathrm{O}$ transpired) in elm growing without mulch or mulched with either $5 \mathrm{~cm}$ or $10 \mathrm{~cm}$ mulch layer. Data are the average of two sampling dates per year, conducted during the summers of 2009, 2010, and 2011. Different letters within the same sampling date indicate significant differences among treatments at $P<0.01$ using Tukey's HSD test. 
tiveness of mixed compost as mulching material in the urban environment in a Mediterranean climate. The mulch properties that may have increased plant growth and whole-canopy gas exchange include: the reduction of soil temperature; the maintenance of soil moisture through the reduction of evaporation; more efficient water use, allowing more carbon to be fixed per unit water transpired; and the slow release of nutrients, as reported in a previous study carried out in similar climate conditions but in experimental plots (Fini and Ferrini 2011). Thus, mulching with compost looks to be an effective, low cost, and highly environmentally friendly technique to improve health, growth, and benefits of urban trees growing in the Mediterranean climate.

Acknowledgments. Thanks to Dr. Alberto Santini for his kind cooperation to this research and for having provided the starting material. We also thank the Direzione Ambiente, Servizio Qualità del Verde, Comune di Firenze for providing the experimental plot, the hand labor and the help provided for establishing the research plot. Work was carried out inside the Laboratorio per la ricerca nel settore vivaistico-ornamentale (LABVIVA), funded by Uniser Consortium Pistoia.

\section{LITERATURE CITED}

Appleton, B.L., J.F. Derr, and B.B. Ross. 1990. The effect of various landscape weed control measures on soil moisture and temperature, and tree root growth. Journal of Arboriculture 16:264-268.

Arnold, M.A., G.V. McDonald, and D.L. Bryan. 2005. Planting depth and mulch thickness affect establishment of green ash (Fraxinus pennsylvanica) and bougainvillea goldenraintree (Koelreuteria bipinnata). Journal of Arboriculture 31:163-170.

Chalker-Scott, L. 2007. Impact of mulches on landscape plants and environment: A review. Journal of Environmental Horticulture 25(4):239-249.

Cogger, C.G. 2005. Potential compost benefits for restoration of soils disturbed by urban development. Compost Science and Utilization, 13:243-251.

Dahiya, R., J. Ingwersen, and T. Streck. 2007. The effect of mulching and tillage on water and temperature regimes of a loess soil: Experimental findings and modelling. Soil and Tillage Research 96:52-63.

Dureya, M.L., R.J. English, and L.A. Hermansen. 1999. A comparison of landscape mulches: Chemical, allelopathic, and decomposition properties. Journal of Arboriculture 25:88-97.

Erhart, E., and W. Hartl. 2003. Mulching with compost improves growth of blue spruce in Christmas tree plantations. European Journal of Soil Biology 29:145-156.

Faithfull, N.T. 2002. Methods in agricultural chemical analysis: A practical handbook. Cabi Publishing, Wallingford, Oxon, UK. $268 \mathrm{pp}$.

Ferrini, F., A. Fini, S. Pellegrini, A. Agnelli, M. Platinetti, P. Frangi, and G. Amoroso. 2008a. Effects of two organic mulches on soil chemical, physical and biological properties. Proceedings of the Third Symposium The Landscape Below Ground, The Morton Arboretum, Lisle, Illinois, U.S.
Ferrini, F., A. Fini, G. Amoroso, and P. Frangi. 2008b. Mulching of ornamental trees: Effects on growth and physiology. Arboriculture \& Urban Forestry 34(3):157-162.

Fini, A., and F. Ferrini. 2011. Effects of mulching with compost on growth and physiology of Acer campestre L. and Carpinus betulus L. Advances in Horticultural Science 25(4):232-238.

Fini, A., F. Ferrini, P. Frangi, G. Amoroso, and R. Piatti R. 2009. Withholding irrigation during the establishment phase affected growth and physiology of Norway maple (Acer platanoides) and linden (Tilia spp.). Arboriculture \& Urban Forestry 35(5):241-251.

Fini, A., P. Frangi, M. Faoro, R. Piatti, G. Amoroso, and F. Ferrini. 2015. Effects of different pruning methods on an urban tree species: A four-year experiment scaling down from the whole tree to the chloroplasts. Urban Forestry \& Urban Greening 14:664-674.

Follett, R.H, R.E. Follett, and A.D. Halvorson. 1992. Use of chlorophyll meter to evaluate the nitrogen status of dry land winter wheat. Communications in Soil Science and Plant Analysis 23:687-697.

Fraedrich, S.W., and D.L. Ham. 1982. Wood chip mulching around maples: Effect on tree growth and soil characteristics. Journal of Arboriculture 8:85-89.

Gilman, E.F., and J. Grabosky. 2004. Mulch and planting depth affect live oak (Quercus virginiana Mill.) establishment. Journal of Arboriculture 30:311-317.

Granatstein, D., and K. Mullinix. 2008. Mulching options for northwest organic and conventional orchards. HortScience $43(1): 45-50$

Graves, W.R. 1998. Consequences of high soil temperatures. pp. 27-35. In: D. Neely and G. Watson (Eds.). The Landscape Below Ground II. Proceedings of an International Workshop on Tree Root Development in Urban Soils. International Society of Arboriculture, Champaign, Illinois, U.S.

Green, T.L., and G.W. Watson. 1989. Effects of turfgrass and mulch on the establishment and growth of bare root sugar maples. Journal of Arboriculture 15:268-271.

Greenly, K., and D. Rakov. 1995. The effect of mulch type and depth on weed and tree growth. Journal of Arboriculture, 21:225-232.

Hanslin, H.M., A. Sæbø, and O. Bergersen. 2005. Estimation of oxygen concentrations in the soil gas phase beneath compost mulch by means of a simple method. Urban Forestry \& Urban Greening 4(1):37-40.

Himelick, E.B., and G.W. Watson. 1990. Reduction of oak chlorosis with wood chip mulch treatments. Journal of Arboriculture 16: 275-278.

Iles, J.K., and M.S. Dosmann. 1999. Effect of organic and mineral mulches on soil properties and growth of 'Fairview Flame' red maple trees. Journal of Arboriculture 25:163-167.

Jones, H. 2004. What is water use efficiency? pp. 27-40. In: M.A. Bacon (Ed.). Water Use Efficiency in Plant Biology. CRC Press, Boca Raton, Florida, U.S.

Jordan, K.K., and S.C. Jones. 2007. Invertebrate diversity in newly established mulch habitats in a Midwestern urban landscape. Urban Ecosystems 10:87-95.

Juma, N.G. 1999. The pedosphere and its dynamics. A systems approach to soil science. Volume 1: Introduction to soil science and soil resources. Salman Productions, Sherwood Park, Alberta, Canada. 315 pp.

Kraus, H.T. 1998. Effects of mulch on soil moisture and growth of desert willow. HortTechnology 8(4):588-590. 
Lakatos, T., T. Buban, W. Muller, F. Polesny, C. Verheyden, and A.D. Webster. 2000. Effectiveness of different groundcover materials to preserve soil water content in a young apple orchard. Acta Horticulturae 525:425-426.

LaMMA. 2014. Consorzio LaMMA. <www.lamma.rete.toscana.it>

Litzow, M., and H. Pellett. 1983. Influence of mulch materials on growth of green ash. Journal of Arboriculture 9:7-11.

Lloyd, J.E., D.E. Herms, B.R. Stinner, and H.A.J. Hoitink. 2000. Nutrient cycling in ornamental landscapes: Effects of fertilization and organic mulches on soil microbial activity, nutrient availability, and plant growth. pp. 33-52. In: A. Siwert, B. Rao, D. Marion (Eds.). Tree and Shrub Fertilization: Proceedings from an international Conference on Tree and Shrub Fertilization. International Society of Arboriculture, Campaign, Illinois, U.S.

Myers, R.J.K., C.A. Palm, E. Cuevas, I.U.N. Gunatilleke, and M. Brossard. 1994. The synchronization of nutrient mineralization and plant nutrient demand. pp. 81-116. In: P.L. Woomer and M.J. Swift (Eds.). The biological management of tropical soil fertility. Wiley, Chichester, UK.

Nilsen, E.T., and O.M. Orcutt. 1996. Physiology of Plants Under Stress: Abiotic Factors. John Wiley \& Sons, Inc., New York, U.S. 689 pp.

Palm, C.A. 1995. The contribution of agroforestry trees to nutrient requirements of intercropped plants. Agroforestry Systems 30:105-124.

Percival, G.C., I.P. Keary, and K. Noviss. 2008. Potential of a chlorophyll content SPAD-meter to quantify nutrient stress in foliar tissue of sycamore (Acer pseudoplatanus), English oak (Quercus robur), and European beech (Fagus sylvatica). Arboriculture \& Urban Forestry 34(2):89-100.

Pickering, J.S., and A. Shepherd. 2000. Evaluation of organic landscape mulches: Composition and nutrient release characteristics. Arboricultural Journal 24(2-3):175-187.

Rhoades, C.C., M.A. Battaglia, M.E. Rocca, M.G. Ryan. 2012. Short- and medium-term effects of fuel reduction mulch treatments on soil nitrogen availability in Colorado conifer forests. Forest Ecology and Management 276:231-238.

Sæbø, A., and F. Ferrini. 2006. The use of compost in urban green areas-A review for practical application. Urban Forestry \& Urban Greening 4:159-169.

Santini, A, F. Pecori, A.L. Pepori, F. Ferrini, and L. Ghelardini. 2010. Genotype $\times$ environment interaction and growth stability of several elm clones resistant to Dutch elm disease. Forest Ecology and Management 260:1017-1025.

Scharenbroch, B.C., and G.W. Watson. 2014. Wood chips and compost improve soil quality and increase growth of Acer rubrum and Betula nigra in compacted urban soil. Arboriculture \& Urban Forestry 40:319-331.

Seneviratne, G. 2000. Litter quality and nitrogen release in tropical agriculture: A synthesis. Biology and Fertility of Soils 31:60-64.

Smith, A.M., and D.A. Rakow. 1992. Strategies for reducing water input in woody landscape plantings. Journal of Arboriculture 18:165-170.

Sonsteby, A., A. Nes, and F. Mage. 2004. Effect of bark mulch and $\mathrm{N}-\mathrm{P}-\mathrm{K}$ fertilizer on yield, leaf nutrient status, and soil mineral nitrogen during three years of production. Acta Agriculturae Scandinavica Section B 54:128-134.

TerAvest, D., J.L. Smith, L., Carpenter-Boggs, D. Granatstein, L. Hoagland, and J.P. Reganold. 2011. Soil carbon pools, nitrogen supply, and tree performance under several groundcovers and compost rates in a newly planted apple orchard. HortScience 46:1687-1694.

Tilander, Y., and M. Bonzi. 1997. Water and nutrient conservation through the use of agroforestry mulches, and sorghum yield response. Plant and Soil 197:219-232.

Tiquia, S.M., J. Lloyd, D.A. Herms, H.A.J. Hoitink, and F.C. Michel, Jr. 2002. Effects of mulching on soil nutrients, microbial activity and rhizosphere bacterial community structure determined by analysis of TRFLPs of PCR-amplified rRNA genes. Applied Soil Ecology 21:31-48.

Townsend, T.G., G.H. Solo, T. Tolaymat, and K. Stook-K. 2003. Impact of chromated copper arsenate (CCA) in wood mulch. Science of the Total Environment 309:173-185.

Watson, G.W. 1988. Organic mulch and grass competition influence tree root development. Journal of Arboriculture 14:200-203.

Watson, G.W., and G. Kupkowski. 1991. Effects of a deep layer of mulch on the soil environment and tree root growth. Journal of Arboriculture 17:242-245.

Whitcomb, C.E. 1979. Factors affecting the establishment of urban trees. Journal of Arboriculture 5:217-219.

Wood, C.W., D.W. Reeves, R.R. Duffield, and K.L. Edmisten. 1992. Field chlorophyll measurement for corn nitrogen status. Journal of Plant Nutrition, 15:487-501.

Alessio Fini (corresponding author)

Dipartimento di Scienze delle Produzioni Agroalimentari e dell'Ambiente

Università degli Studi di Firenze

Viale delle Idee, 30, 50019

Sesto Fiorentino (Firenze)

alessio.fini@unifi.it

Ciro Degl'Innocenti

Direzione Ambiente

Servizio Qualità del Verde

Comune di Firenze

Francesco Ferrini

Dipartimento di Scienze delle Produzioni Agroalimentari e

dell'Ambiente

Università degli Studi di Firenze

Viale delle Idee, 30, 50019

Sesto Fiorentino (Firenze) 
Résumé. Les effets de composts mélangés utilisés comme matériau de paillage sur la croissance et sur la physiologie d'ormes nouvellement plantés furent évalués sur une période de trois ans après leur plantation dans un parc urbain. Les arbres pourvus d'un paillis de compost sont généralement plus hauts (de $+10 \%$ et de $+19 \%$ respectivement pour ceux pourvus d'une couche de $5 \mathrm{~cm}$ ou de 10 $\mathrm{cm}$, comparativement aux arbres témoins), montrent un plus gros diamètre du tronc ( $\mathrm{de}+13 \%$ et de $+29 \%)$ et ont une croissance plus longue pour la pousse de l'année en cours ( de $+46 \%$ et de +56 $\%)$. Des effets limités ont été constatés en ce qui concerne l'assimilation du carbone calculé par unité de surface foliaire (de - 0,1\% et + de $0,3 \%$ ), par contre, on a remarqué une meilleure assimilation du carbone sur l'arbre entier (de $+7 \%$ et de $+59 \%$ respectivement pour ceux pourvus d'une couche de paillis de $5 \mathrm{~cm}$ ou de $10 \mathrm{~cm}$, comparativement aux arbres témoins) en raison d'une plus grande surface foliaire totale des arbres avec paillis. Le paillage a également augmenté la teneur en chlorophylle (de $+4 \%$ et de $+7 \%$ respectivement pour ceux pourvus d'une couche de $5 \mathrm{~cm}$ ou de $10 \mathrm{~cm}$ ). Les résultats obtenus dans cette étude démontrent à quel point le paillage de compost augmente la croissance, le stockage du carbone et présente une efficacité accrue pour l'utilisation de l'eau sur les arbres plantés en milieu urbain caractérisé par des étés chauds et secs.

Zusammenfassung. In einem urbanen Park wurden die Einflüsse von gemischtem Kompost als Mulchmaterial auf Wachstum und Physiologie von neu gepflanzten Ulmen über eine dreijährige Periode nach der Pflanzung getestet. Mit Kompost gemulchte Bäume hatten allgemein eine grössere Höhe $(+10 \%$ und $+19 \%$ bei einer Aufbringung von $5 \mathrm{~cm}$ und bzw. $10 \mathrm{~cm}$ im Vergleich zur Kontrolle), Stammdurchmesser (+13\% bzw. 29\%) und diesjähriger Triebzuwachs (+46\% bzw. 56\%). In Bezug auf die Kohlenstoffassimilation basierend auf einer Blattflächeneinheit wurden begrenzende Einflüsse gefunden, $(-0.1 \%$ and $+0.3 \%)$, aber die gesamte Kohlenstoffassimilation des Baumes nahm bei bemulchten Bäumen zu ( $+7 \%$ und $+59 \%$ bei $5 \mathrm{~cm}$ bzw. $10 \mathrm{~cm}$ Mulchauftrag in Vergleich zur Kontrollgruppe) wegen der grösseren totalen Blättfläche der gemulchten Bäume. Das Mulchen hob auch den Chlorophyllgehalt an $(+4 \%$ und $+7 \%$ fbei $5 \mathrm{~cm}$ bzw. $10 \mathrm{~cm}$ Mulchauftrag in Vergleich zur Kontrollgruppe). Die in dieser Studie erzielten Ergebnisse zeigen, wie Mulchen mit Kompost das Wachstum und Kohlenstoffspeicherung vergrössert und die Wasserverbraucheffezienz von Bäumen an urbanen Standorten verbessert, die durch heisse trockene Sommer gekennzeichnet sind.

Resumen. Los efectos de la composta como material de acolchado en el crecimiento y la fisiología de árboles de olmo recién plantados fueron evaluados durante un período de tres años después de la plantación en un parque urbano. Los árboles acolchados con composta generalmente tuvieron mayor altura $(+10 \%$ y + $19 \%$ para tratamientos en capas de $5 \mathrm{~cm}$ y $10 \mathrm{~cm}$, respectivamente, en comparación con el control), el diámetro del tronco $(+13 \%$ y + $29 \%)$ y el crecimiento corriente anual $(+46 \%$ y $+56 \%)$. Se encontraron efectos limitados con respecto a la asimilación de carbono cuando se considera en base de unidad de área foliar $(-0,1 \%$ y + $0,3 \%)$, pero la asimilación completa de carbono aumentó en los árboles acolchados $(+7 \% \mathrm{y}+59 \%$ para $5 \mathrm{~cm}$ y $10 \mathrm{~cm}$ de tratamientos, respectivamente, en comparación con el control) debido a la mayor área foliar de los árboles acolchados. El mulching también aumentó el contenido de clorofila $(+4 \%$ y $+7 \%$ en tratamientos de $5 \mathrm{~cm}$ y $10 \mathrm{~cm}$, respectivamente). Los resultados obtenidos en este estudio muestran cómo la composta incrementó el crecimiento, el almacenamiento de carbono, y la mejora de la eficiencia del uso del agua de los árboles plantados en un entorno urbano caracterizado por veranos cálidos y secos. 